\title{
Locational Determinants of Foreign Direct Investments in Nigeria
}

\author{
Babatunde Olufemi Oke (Corresponding author) \\ Department of Finance, Faculty of Business Administration, University of Lagos \\ Akoka, Lagos, Nigeria \\ Tel: 234-803-443-2262 E-mail: boke@unilag.edu.ng \\ John Emeka Ezike \\ Department of Finance, Faculty of Business Administration, University of Lagos \\ Akoka, Lagos, Nigeria \\ Tel: 234-802-308-9125Ｅ-mail: john_ezike@yahoo.com \\ Samuel Obinna Ojogbo \\ Department of Finance, Faculty of Business Administration, University of Lagos \\ Akoka, Lagos, Nigeria \\ Tel: 234-803-247-3192Ｅ-mail: omitakoko@yahoo.com
}

Received: October 31, 2011

Accepted: February 15, 2012

Published: April 1, 2012

doi:10.5539/ibr.v5n4p103

URL: http://dx.doi.org/10.5539/ibr.v5n4p103

\begin{abstract}
In this paper, we examine country specific or locational determinants of foreign direct investments (FDI) in Nigeria. Using time series data from 1975-2008 and applying Generalized Method of Moments (GMM) with autoregressive error technique, we find that the index of government expenditure, index of energy consumption, and the indicator of political stability are positive and significant predictors of FDI in Nigeria at 5 percent significance level. Other locational variables suggested in the literature such as inflation rate, exchange rate, market size, infrastructure and human capital are however not significant determinants of FDI in the country. We thus recommend that the varying influences of these variables should be noted for appropriate policy actions in order to fully attract FDI into the country.
\end{abstract}

Keywords: Foreign direct investments, Infrastructural development, Human capital development, Index of energy consumption

\section{Introduction}

The Nigerian government at the advent of democratic government in May 1999 enthusiastically announced its desire to attract and embrace foreign direct investments (FDI) into the country. This renewed interest emanated from the perceived opportunities derivable from utilizing this form of foreign capital injection into the economy (Adeseyoju 2001). In the first instance, FDI is believed to be more stable and easier to service than commercial bank credit or portfolio investments. FDI is usually a long-term economic activity in which repatriation of profits only occur when the project generates enough returns. Secondly, Nigeria is expected to access modern technologies through FDI to upgrade the country's productive capacities through adaptation of such technologies to her local conditions. Thirdly, on account of its integrated network of activities across the globe, FDI is potent enough to integrate Nigeria into the global market (both for existing economic activities as well as new ones that are likely to emerge). Such penetration into international market engenders substantial capacity building and economies of scale, among others (Hood \& Young 1979; Aremu, 2000). Moreover, FDI provides employment opportunities to underutilized factors of production, guarantees formal and informal trainings, and returns to domestic resource owners in the Nigerian economy. As multinational corporations (MNCs) through their affiliates (branches, subsidiaries and associates) integrate Nigerian economy into their system, the country's domestic productive capacities are expected to be improved.

Indeed, the need for a paradigm shift from a largely inefficient public sector led economy to a more efficient private sector led economy, among other things, motivated the introduction of the Structural Adjustment Programme (SAP) in 
Nigeria in 1986. Thus, policies such as financial liberalization, currency devaluation, privatization and commercialization of public enterprises, removal of price controls and subsidies were introduced. Also, actions were taken to remove all obstacles to the growth of private investments even as efforts were made to provide incentives to existing, as well as potential investors Okwo (1999).

Policymakers in the country further realized the need to embark on proactive investment promotion strategy in order to promote the country to potential investors abroad. Indeed, key issues relating to investment climate and business operating conditions were to be taken seriously. In the era of globalization of markets, investment and technology, investment capital has become rather more selective in its search for outlets and growth. Given the emergence of trading and regional blocks, the competition for scarce capital has become even more intensified. Policymakers in Nigeria then realized that the country could no longer take for granted that foreign capital would flow into the country in line with global economic conditions. The challenge therefore was to formulate and implement policies that would help to retain existing investments (and sustain their capacity) as well as attract new investors with carefully designed and enduring incentive structure. Such policies would involve not just the creation of favourable tariff, tax and exchange regimes but also the qualitative assurances of warm, cordial and mutually beneficial relationship between an investor and the host country.

Towards the realization of the aforementioned policy thrust, the Nigerian government introduced laws that removed restrictions that were hitherto placed on foreign investments and provided guarantees that no investment will be nationalized or expropriated by any government of the federation. Also, no person owning capital of any enterprise, wholly or in conjunction with others, will be compelled by law to surrender his interest to any person. The provision on the guarantees against nationalization or expropriation is worth noting. It was meant to further assuage the fears of foreign investors. Even where in extreme and rare circumstances, due perhaps to considerations of the national interest, acquisitions will be immediately followed by prompt payment of fair and adequate compensation. A right of access to the law courts for the determination of the investors' interest or right and the amount of compensation to which such investor is entitled is also guaranteed. In addition, the Nigerian Investment Promotion Commission was established with the task of coordinating and monitoring all investment promotion activities in Nigeria. The Commission is to, among other things: initiate and support measures which shall enhance the investment climate in Nigeria for both Nigerian and non-Nigerian investors; promote investment in and outside Nigeria through effective promotional means; collect, collate, analyze and disseminate information about investment opportunities and sources of investment capital and advise investors on their request on the availability, choice or sustainability of partners in joint venture project; issues guidelines and procedure, which specify priority areas of investment and prescribe applicable incentives and benefits, which are in conformity with government policy; and Negotiate specific incentive packages for the purpose of promoting identified strategies or major investment as the Commission may specify in consultation with appropriate government agencies.

In spite of all these incentives, Nigeria has failed to attract substantial inflow of FDI over time. Although FDI grew from USD 1079.27million in 1995 to USD 8824.80 million in 2006, FDI inflow has consistently fallen below remittances inflow since 2007 and is even about half of the latter in 2009. (See Table 1 and Figure 1). An important question then is: How come Nigeria is unable to attract substantial FDI inflow in spite of all the incentives in place? Put differently, what are the determinants of foreign direct investment in Nigeria?

The purpose of this study is to ascertain the host-country specific (or locational) determinants of FDI into Nigeria. This becomes imperative since a firm's method of entry into a foreign market and eventual system of management are often heavily dependent upon the motives underlying the investment. Therefore, any theoretical or empirical attempt to provide guidance in international investment decision making and management cannot fail to include an assessment and diagnosis of the factors that account for the decision to go abroad. Also, Government policy on FDI (for example, a policy for attracting such investment) that is designed without a clear recognition and adequate understanding of the factors that determine foreign investment is likely to be predicated upon incorrect premises and apt to prove ineffective. Moreover, the wide variations in the inflow of FDI both over time and among developing countries also raise question of what factors influence the inflows of FDI to developing countries.

This paper is divided into five sections. Following this introductory section, section II reviews relevant theoretical and empirical studies while the methodology of the study is explained in section III. The findings of this study are presented in section IV while section $\mathrm{V}$ contains the concluding remarks.

\section{Literature Review}

FDI is defined in the IMF Balance of Payments Manual (1993) as "investment that involves a long-term relationship reflecting a lasting interest of a resident entity in one economy (direct investor) in an entity resident in an economy other than that of the investor. The direct investor's purpose is to exert a significant degree of influence on the 
management of the enterprise resident in the other economy". To the World Bank (2010), FDI is the net inflow of investment to acquire a lasting management interest (10 percent or more of voting stock) in an enterprise operating in an economy other than that of the investor. It is the sum of equity capital, reinvestment of earnings, other long-term capital, and short-term capital as shown in the balance of payments. WTO (1996) says that "FDI occurs when an investor based in one country (the home country) acquires an asset in another country (the host country) with the intent to manage that asset. The management dimension is what distinguishes FDI from Portfolio investment (PI) in foreign stocks, bonds, and other financial instruments. In most cases, the investor and the asset being managed abroad are business firms. In such cases, the investor is typically referred to as the "parent firm" and the asset as the "affiliate" or "subsidiary". Three main categories of FDI are identified by WTO (1996), namely: (a) Equity capital, which is the value of the Multinational Corporation (MNC)'s investments in shares of an enterprise in a foreign country; (b) reinvested earnings which are the MNC's share of affiliate earnings not distributed as dividends or remitted to the MNC: and (c) other capital which refers to short or long-term borrowing and lending of funds between the MNC's and the affiliate.

Root (1990) notes that FDI "is the distinctive feature" of MNC. Hence a theory of FDI is also a theory of MNC as an actor in the world economy. He further explains that FDI is the extension of an enterprise from its home country into a foreign host country and this extension involves the flow of capital, technology, and entrepreneurial skills to the host economy where they are combined with local factors in the production of goods for the local and/or export markets. This transfer of a "bundle" of factor services remains under the control of the investing (parent) firm, as do the subsequent production and marketing activities of the subsidiary in the host country. Dunning, (1993b) concurs that FDI involves the transfer of a package of resources (e.g., technology, management skills, organizational capacity and entrepreneurship) across national boundaries, the de jure governance of which continues to remain in the hands of the transferring firms or (in the case of a substantial local equity interest) is shared with the transferring firm. He defines MNC as an enterprise that engages FDI and "owns or controls value-adding activities in more than one country". In order words, "The usual mode of ownership and control is by FDI". Sodersten and Reed (1994) emphasize that for MNC to come into existence FDI must be in place and that the distinguishing feature of FDI is the exercise of control over decision-making in an enterprise located in one country by investors located in another.

Dunning (1993a) distinguishes between FDI and foreign indirect (or portfolio or contractual) investment. "Firstly, the former involves the transfer of a package of assets or intermediate products, which includes money, capital, management and organizational enterprise, technology, entrepreneurship and access to markets across boundaries; the latter involves only the transfer of money capital. Secondly, unlike arm's length trade in assets and intermediate products, foreign direct investment does not involve any change in ownership: in order words, the control of decision taking over the use of the transferred resources remains in the hands of the investing entity. Put another way, while the indirect exchange of assets and intermediate products is organized by the market, the direct exchange is administered by, and within, investing hierarchies".

Prakash and Assaf (2001), Hausmann and Fernandez-Arias (2000), Dadush et al. (2000), and Lipsey (2001) note that FDI, in sharp contrast to other forms of capital flows has proven to be resilient during financial crises, such as East Asian crisis of 1997-98, Mexican crisis of 1994-95 and the Latin American debt crisis of the 1980s. This resilience, among other benefits, makes many developing countries to favour FDI over other forms of capital. Hausmann and Fernandez-Arias (2000) further suggest that many host countries view international debt flows, especially of the short-term variety, as "bad cholesterol". "It (short-term lending from abroad) is driven by speculative considerations based on interest rate differentials and exchange rate expectations not on long-term considerations. Its movement is often the result of moral hazard distortions such as implicit exchange rate guarantees or the willingness of governments to bailout the banking system. It is the first to run for the exit in times of trouble and is responsible for the boom-burst cycles of the 1990s". FDI on the other hand is viewed as "good cholesterol" because it confers so many benefits and is thought to be "bolted down and cannot leave so easily at the first sign of trouble".

Dunning (1993b) identifies four main reasons prompting firms to undertake FDI. These are: "to acquire natural resources, the price of which (net of transportation costs) is lower and/or the quality is higher than in the investing country; to service foreign markets, particularly in the country in which the investment is being made; to restructure existing foreign value-added activities, so as to improve overall efficiency and change the range of products produced; and to acquire assets which might be complementary to existing assets, or competitive to them, so as to reduce risk, capture the economies of scale or synergy, or generally strengthen the acquiring firms' competitive position in national or world market." Based on these four main motives, Dunning (1993a), recognizes four types of multinational enterprises, namely: Resource seekers; Market seekers; Efficiency seekers; and Strategic asset or capability seekers. 
Moreover, Dunning (1993a) posits that the theory of the determinants of FDI must explain the location of value-adding activities as well as the ownership and organization of these activities. Thus, it is imperative to follow and incorporate the theory of international resource allocation (factor endowments) and focus on the location of production. It also must include the theory of economic organization, which emphasizes ownership of that production and the ways in which the transactions relating to it are managed and organized.

Indeed, the determinants of FDI can be situated in many theories. These include: the Neoclassical Trade Theory, that posit that capital movement can be attributable to differences in capital returns (Aliber, 1970); the Proximity-Concentration Hypothesis or horizontal FDI model (Krugman, 1983; Brainard, 1993; Markusen, 1984; Ethier, 1986; Horstmann \& Markusen, 1992); the product cycle (Vernon, 1966); the Factor-Proportions Hypothesis, theory of international fragmentation or vertical FD model (Helpman, 1984; Dixit \& Grossman, 1982; Deardorff, 2001); the risk diversification model (Agmon \& Lessard, 1977; Michel \& Shaked, 1986); the Knowledge Capital Model (Markusen, 1997); Ownership advantages such as monopolistic advantage (Hymer, 1960; Kindleberger, 1969; Caves, 1971) and the Internalisation theory (Buckley \& Casson, 1979; Swedenborg, 1979; Rugman, 1981; Hennart, 1982); as well as the Ownership, Locational and internalisation (OLI) model (Dunning, 1977; 1979; 2001). Moreover, Kojima (1973; 1978; 1982; 1990), and Kojima and Ozawa (1984) propound the macro-economic theory of FDI to explain which activities of firms are best undertaken in particular countries and that the distribution of value-added activity both within a country and between countries can only be explained in terms of comparative costs and benefits.

In line with the foregoing, many studies have empirically tested some of the variables identified by some of the theories mentioned above. In line with the OLI model, Dunning (1980) shows that location-specific variables (such as market size, transport costs, factor costs, political stability, trade barriers and infrastructure quality) are the main drivers of FDI inflow. Using Gross National Product (GNP) or Gross Domestic Product (GDP) as a measure of market size, Dunning (1980) examination of FDI determinants in US, that of Swedenborg (1979) in Sweden, Schneider and Frey (1985) of FDI into some 54 developing countries and Papanastassiou and Pearce (1990) study of FDI into UK demonstrate this variable to be positively and significantly associated with inward FDI. Papanastassiou and Pearce (1990) also show that GNP per capita positively influence FDI in UK while Root and Ahmed (1979) conclude that the rate of growth of GDP is a more significant discriminating factor than the size of the GDP. Swedenborg (1979) however finds GNP to be negatively, and sometimes significantly, related to inward FDI.

An important FDI issue concerns the motivation behind a firm's choice to service a foreign market through affiliate production instead of licensing arrangements or exporting. The justification has been found in the existence of firm-specific intangible assets (or ownership advantages) such as research and development (R\&D), advertising expenditure, managerial skill and technology and firm size, etc. Caves (1974) and Swedenborg (1979) have shown these to be important determinants of FDI. Moreover, Brainard (1993) reveals that Proximity-Concentration Hypothesis and horizontal FDI model explain FDI determination. In addition, policy factors like corporate tax rates and tax concessions (Root \& Ahmed, 1978; Rolfe et al., 1993; Bénassy-Quéré et al., 2001) and risk factors like market risk, the exchange rate and the interest rate (Cushman, 1988; Klein \& Rosengren, 1994) empirically account for FDI inflow.

Asiedu (2002) is of the opinion that the determinants of FDI in one region may not be the same for other regions. In the same vein, the determinants of FDI in countries within a region may be different from one another and from one period to another. Also, Obwona (2001) shows that macroeconomic policy consistency and political stability are important drivers of FDI into Uganda while Hanson (2001) indicates that factor price differentials motivate FDI flows.

Aremu (1997) categorizes the various types of foreign investment in Nigeria into five: wholly foreign owned; joint ventures; special contract arrangements; technology management and marketing arrangements; and subcontract co-production and specialization. With respect to FDI determinants in Nigeria, Ekpo (1995) reports that political regime, real income per capita, rate of inflation, world interest rate, credit rating and debt service are the key explanatory factors. Odozi (1995) reveals the negative effects of macroeconomic policies on FDI inflow before the structural adjustment programme (SAP) in Nigeria. These macro-policies also led to the proliferation and growth of parallel markets and sustained capital flight in the country. Moreover, Anyanwu (1998) identifies change in domestic investment, change in domestic output or market size, indigenization policy, and change in openness of the economy as major determinants of FDI. He further notes that the abrogation of the indigenization policy in 1995 encourages FDI inflow into Nigeria. In addition, Oke (2001) shows that host country market size, openness of the economy to foreign trade, and political stability, positively affect FDI inflow to Nigeria while exchange rate, attractiveness of host country's domestic policies, domestic inflation rate, and physical infrastructure negatively influence realized FDI in the country between 1970 and 2000. 


\section{Methodology}

In this study, we focus on the country-specific or locational determinants of FDI in Nigeria between 1975 and 2008. Employing the Generalized Method of Moments (GMM) estimation technique, we add a one period autoregressive (AR) term to the equation specification in order to account for serial correlation. To analyze a total of thirty three (33) time series observations involved during the estimation period, we use EViews 7 statistical package.

\subsection{Specification of the Model}

The implicit form of the model of the locational determinants of FDI in Nigeria is specified as follows:

$$
\begin{aligned}
\operatorname{LogFDI} I_{t} & =\beta_{0}-\beta_{1} \operatorname{LogINF}_{t}+\beta_{2} \log G D P_{t}+\beta_{3} \operatorname{LogINFDEV} V_{t}+\beta_{4} \operatorname{LogGOVEXP}_{t} \\
& +\beta_{5} \log H C A_{t}-\beta_{6} \operatorname{LogPOLSTAB_{t}}+\beta_{7} \operatorname{LogIEC} C_{t}+\beta_{8} \operatorname{LogEXCR}_{t}+A R(1)
\end{aligned}
$$

In order to satisfy the order of condition for identification, we use the following instrumental variables:

$\operatorname{LogFDI} I_{t-1} ; \quad \log \mathrm{INF}_{t-1} ; \quad \log \operatorname{LDP}_{t-1} ; \quad \operatorname{LogINFDEV} V_{t-1} ; \quad \operatorname{LogGOVEXP} P_{t-1} ; \quad \operatorname{LogHCA} A_{t-1} ; \quad \operatorname{LogPOLSTAB} B_{t-1} ; \quad \operatorname{LogIEC} C_{t-1}$; $\log E X C R_{t-1}$.

Where, $F D I=$ Foreign direct investment; $I N F=$ Inflation rate; $G D P=$ Gross domestic product; INFDEV $=$ Infrastructural development; GOVEXP = Government expenditure; HCAP = Human capital development; POLSTAB $=$ Political stability; $I E C=$ Index of energy consumption; $E X C R=$ Exchange rate. We expect 'a priori', $\beta_{2}, \beta_{3}, \beta_{4}, \beta_{5}$, $\beta_{6}$, and $\beta_{7}>0$ while $\beta_{1}$ and $\beta_{8}<0$. In order words, all the independent variables, except inflation rate and exchange rate, are expected to positively influence FDI.

\subsection{The Variables}

DOMESTIC INFLATION RATE (INF): A high rate of inflation is an indication of macroeconomic instability and of the failure of the government to manage the economy (Fisher, 1993). Inflation beyond certain threshold will contract private investments (including foreign) by increasing risk and distorting price signals in the economy. (Dornbusch \& Reynoso, 1989). Foreign investors seek economic stability as assurance for their investments. A negative relationship is thereby hypothesized to exist between levels of FDI and inflation rate.

GROSS DOMESTIC PRODUCT (GDP): The market size is an important 'pull' factor since a large market size potentially leads to increase in demand for products and services offered by foreign investors (Dunning, 1993a). Following Asiebu (2002) and Erdal and Tatoglu (2002), we use Gross Domestic Product (GDP) as a measure of the market size and postulate a positive relationship between FDI and GDP.

INFRASTRUCTURAL DEVELOPMENT (INFDEV): Foreign investors would prefer a host country with a good infrastructure, which will facilitate communication, transportation and distribution, and impact positively on returns on investments (Asiedu, 2002; Erdal \& Tatoglu, 2002; Jenkins \& Thomas, 2002). We expect a positive relationship between infrastructure development and FDI.

HUMAN CAPITAL DEVELOPMENT (HCAP): The importance of education to economic growth is proxied by the ratio of secondary and tertiary institution enrolment in the population. Following Balasubramanyan, Mohammed, and Sapsford (1996), we expect a direct relationship between human capital and FDI.

POLITICAL STABILITY: It is widely acknowledged that when a country is politically stable its economy will grow and development will be enhanced. An unstable political climate will have the opposite effect in addition to discouraging investments, both local and foreign. We use dummy variable to capture periods without coups d'état in this study. We expect a direct relationship between the measure and FDI.

INDEX OF ENERGY CONSUMPTION (IEC): Given the availability of data we use electric power consumption as a proxy for this variable. The variable is measured as per capita electricity power consumption.

FOREIGN EXCHANGE RATE (EXCR): An overvalued exchange rate or highly distorted foreign exchange rate is expected to discourage exports and negatively affect FDI. Frost and Stein (1989) indicate that the values of the US dollar and the propensity of foreign firms to invest in the US are negatively and significantly related since the former alter relative wealth across nations.

\section{Research Findings}

From the GMM result in Table 2, we obtained the following:

$\operatorname{LogFDI}=16.11+0.16 \log \mathrm{INF}_{t}-0.16 \log G D P_{t}-1.98 \operatorname{LogINFDEV} V_{t}+0.94 \log G O V E X P_{t}+1.21 \operatorname{LogHCA} A_{t}+$ $0.65 \operatorname{LogPOLSTAB} B_{t}+0.74 \operatorname{LogIEC} C_{t}+0.19 \log _{\operatorname{LXXR}}-0.48 A R(1)+\mu_{t}$

The results of the GMM as presented in Table 2 below show that $\log ($ GOVEXP) (the index of government expenditure and of fiscal policy), $\log (I E C)$ (Index of energy consumption), and POLSTAB (indicator of political 
stability) are positive and significant predictors of FDI in Nigeria at 5 percent significance level during the period under consideration. The parameter estimates thus comply with the 'a priori' expectations of a positive relationship between FDI and each of these variables. It is not surprising that power availability, government expenditure and a stable polity will enhance FDI in a country that is still hugely driven by the public sector. All the remaining explanatory variables however are insignificant determinant of FDI at 5 percent level and only the indicator of human capital is rightly signed among them. Both Inflation and exchange rate enter with a negative sign while the indicator of market size (GDP) and the index of infrastructure enter with negative sign. It is indeed surprising and paradoxical that market size and infrastructure negatively influenced FDI while inflation rate and exchange rate have positive influence. It perhaps could mean that both rate of inflation and exchange rate have not reached the threshold that discourages FDI while both GDP and infrastructure are too low to attract FDI into the country.

The results further show that the coefficient of determination $\left(\mathrm{R}^{2}\right)$ value is high at 0.94 and is statistically different from zero. Thus, over $94 \%$ of the variations in FDI can be attributed to variations in the independent variables. Moreover, the $\mathrm{J}$ statistic of almost zero means that the model is well specified.

\section{Conclusion}

In this paper, we examine country specific or locational determinants of FDI in Nigeria. The results of the GMM as employed in this study the index of government expenditure, index of energy consumption, and the indicator of political stability are positive and significant predictors of FDI in Nigeria at 5 percent significance level from 1975 to 2008. Inflation, exchange rate, market size, index of infrastructure and the indicator of human capital are not significant determinant of FDI, although the latter is rightly signed. The result indicated that there is a very strong and positive correlation between the explanatory variables and FDI as indicated by the coefficient of determination of $94 \%$. It is recommended that guided training and integration be given to the human resources of the country to enable them to contribute positively to economic growth wherever they find themselves employed either with foreign or with indigenous firms and whichever sector they are in. The power sector may be further liberalized to allow for its more positive impact on FDI. Greater policy sensitivity towards infrastructural development is needed so that the cost of doing business in Nigeria can be significantly reduced thereby increasing the inflow of FDI into the country. The need for improvement in infrastructure in the country cannot be overemphasized.

\section{References}

Adeseyoju, A. (2001, October 1). Attracting foreign investors to Nigeria. Daily Times Newspaper, pp. 31.

Agmon, T., \& Lessard, D. R. (1977). Investor recognition of corporate international diversification. Journal of Finance, 32 (September), 1049-55. http://dx.doi.org/10.2307/2326511

Aliber, R. Z. (1970). A Theory of Direct Foreign Investment. In C. Kindleberger (Ed.), The International Corporation. Cambridge. MA: MIT Press.

Anyanwu, J. C. (1998). An econometric investigation of the determinants of foreign direct investment in Nigeria: Rekindling investment for economic development in Nigeria. Selected papers in Annual conference, Nigerian Economic Society, Ibadan.

Aremu, J. (2000, October 9). Forty years of flow of foreign direct investment into Nigeria: Too many defect. Financial Standards Newspaper, pp. 38-39.

Aremu, J. A. (1997). Foreign private investment: Determinants, performance and promotion. CBN Bulletin, 108-112.

Asiedu, E. (2002). On the determinants of foreign direct investment to developing countries: Is Africa different. World Development, 30(1), 107-19. http://dx.doi.org/10.1016/S0305-750X(01)00100-0

Balasubramanyan, V. N., Mohammed, A. S., \& Sapsford, D. (1996). Foreign direct investment and growth in EP and IS countries. Economic Journal, 106, 92-105. http://dx.doi.org/10.2307/2234933

Brainard, S. L. (1993). An empirical assessment of the proximity concentration trade off between multinational sales and trade. NBER Working Paper No. 4580. http://www.nber.org/papers/w4580.pdf

Buckley, P. J., \& Casson, M. (1976). The Future of the Multinational Enterprise. London: Macmillan.

Caves, R. E. (1971). International corporations: the industrial economics of goreign investment. Economica, 38, 1-27. http://dx.doi.org/10.2307/2551748

Cushman, D. O. (1988). Exchange-rate uncertainty and foreign direct investment in the United States. Weltwirtschaftliches Archiv, Bd. 124, H. 2, pp. 322-336. http://dx.doi.org/10.1007/BF02706782 
Dadush, U., Dasgupta, D., \& Ratha, D. (2000). The role of short-term debt in recent crises. Finance and Development, 37 (4), 54-57. http://www.imf.org/external/pubs/ft/fandd/2000/12/dadush.htm

Deardorff, A. V. (2001). Fragmentation in simple trade models. North American Journal of Economics and Finance, 12, 121-137. http://dx.doi.org/10.1016/S1062-9408(01)00043-2

Dixit, A. K., \& Grossman, G. M. (1982). Trade and protection with multistage production. Review of Economic Studies, 49, 583-594. http://dx.doi.org/10.2307/2297288

Dornbusch, R., \& Reynoso, A. (1989). Financial factors in economic development. American Economic Review Papers and Proceedings, 79(2), 204-209. http://dx.doi.org/10.2307/2534470

Dunning, J. H. (1977). Trade, location of economic activity and the MNE: A search for an eclectic approach. In B. Ohlin et al. (Eds.), The International Allocation of Economic Activity (pp. 395-418). London: Holmes and Meier.

Dunning, J. H. (1979). Explaining the changing pattern of international production: in defence of the eclectic theory. Oxford Bulletin of Economics and Statistics, 41, 269-296. http://dx.doi.org/10.1111/j.14680084.1979.mp41004003.x

Dunning, J. H (1980). Toward an eclectic theory of international production: Some empirical tests. Journal of International Business Studies, 11(1), 9-31. http://dx.doi.org/10.1057/palgrave.jibs.8490593

Dunning, J. H. (1993a). Multinational Enterprises and the Global Economy. Edinburgh Gate, England: Addison Wesley Longman Ltd.

Dunning, J. H. (1993b). Introduction: The Nature of Transnational Corporations and their Activities. In J. R. Dunning (Ed.), The Theory of Transnational Corporations (Vol. 1 pp. 1-16). London and New York: Routledge.

Ekpo, A. H. (1995). Foreign direct investment in Nigeria: Evidence from time series data. CBN Economic and Financial Review, 35(1), 59-78.

Erdal, F., \& Tatoglu, E. (2002). Locational determinants of foreign direct investment in an emerging market economy: Evidence from Turkey. Multinational Business Review, 10(1), 21-27. http://www.econturk.org/Turkisheconomy/fuatekrem.pdf

Ethier, W. (1986). The multinational firm. Quarterly Journal of Economics, 101, 805-833. http://dx.doi.org/10.2307/1884179

Eviews. (2010). EViews 7.0 Enterprise Edition Quantitative Micro Software, LLC, Irvine, CA.

Fisher, S. (1993). The role of macroeconomic factors in growth. Journal of Monetary Economics, 32 (3), 458-512.

Froot, K. A., \& Stein, J. C. (1991). Exchange rates and foreign direct investment: An imperfect. capital markets approach. The Quarterly Journal of Economics, 106(4), 1191-1217. http://dx.doi.org/10.2307/2937961

Green, R. T., \& Cunningham, W. H. (1975). The determinants of U.S. foreign investment: An empirical examination. Management InternationaSl Review, 15(2/3), 113-120. http://www.jstor.org/stable/40227213

Hanson, G. H. (2001). Should countries promote foreign direct investment? UNCTAD Discussion Paper No. 9 Feb. http://www.unctad.org/en/docs/pogdsmdpbg24d9.en.pdf

Hausmann, R., \& Fernandez-Arias, E. (2000). Foreign direct investment: Good cholesterol?. IDB Working Paper No. 348. http://dx.doi.org/10.2139/ssrn.1817215

Helpman, E. (1984). A simple theory of trade with multinational corporations. Journal of Political Economy, 92, 451-471. http://dx.doi.org/10.1086/261236

Hennart, J. F. (1982). A Theory of Multinational Enterprise. Ann Arbor: University of Michigan Press.

Hood, N., \& Young, S. (1979). The Economics of Multinational Enterprise. London: Longman,

Horstmann, I. J., \& Markusen, J. R. (1992). Endogenous market structures in international trade (natura facit saltum). Journal of International Economics, 32, 109-129. http://dx.doi.org/10.1016/0022-1996(92)90038-L

Hymer, S. H. (1976). The International Operations of National Firms: A Study of Direct Investment. Cambridge, MA: MIT Press.

Jenkins, C., \& Thomas, L. (2002). Foreign Direct Investment in Southern Africa: Determinants, Characteristics and Implications For Economic Growth and Poverty Alleviation. http://www.csae.ox.ac.uk/reports/pdfs/rep2002-02.pdf

Jones, R. W., \& Kierzkowski, H. (2005). International fragmentation and the new economic geography. The North American Journal of Economics and Finance, 16(2), 255-269. http://dx.doi.org/10.1016/j.najef.2004.11.005 
Kindleberger, C. P. (1969). American Business Abroad: Six Lectures on Foreign Direct Investment. New Haven: Yale University Press.

Klein, M. W., \& Rosengren, E. (1994). The real exchange rate and foreign direct investment in the United States : Relative wealth vs. relative wage effects. Journal of International Economics, 36(3-4), 373-389. http://dx.doi.org/10.1016/0022-1996(94)90009-4

Kojima, K. (1973). Reorganization of north-south trade: Japan's foreign economic policy for the 1970's. Hitosubashi Journal of Economics, $\quad$ 13(February), $\quad$ 1-28. http://hermesir.lib.hitu.ac.jp/rs/bitstream/10086/8012/1/HJeco0130200010.pdf

Kojima, K. (1978). Direct Foreign Investment: A Japanese Model of Multinational Business Operations. London: Croom Helm.

Kojima, K. (1982). Macroeconomic versus international business approach to foreign direct investment. Hitosubashi Journal of Economics, 23(1), 1-19. http://hermesir.lib.hitu.ac.jp/rs/bitstream/10086/7932/1/HJeco0230100010.pdf

Kojima, K., \& Ozawa, T. (1984). Micro and macro economic models of foreign direct investment: Towards a synthesis. Hitosubashi Journal of Economics, 25(2). 1-20. http://hdl.handle.net/10086/7907

Krugman, P. R. (1983). The "New Theories" of International Trade and the Multinational Enterprise. In C. P. Kindleberger \& D. B. Audretsch (Eds.), The multinational corporation in the 1980s. Cambridge, MA: MIT Press.

Lim, D. (1983). Fiscal incentives and direct foreign investment in less developed countries. Journal of Development Studies, 19(2), 207-212. http://dx.doi.org/10.1080/00220388308421859

Lipsey, R. E. (2001). Foreign direct investors in three financial crises. NBER Working Paper No. 8084. National Bureau of Economic Research, Cambridge, MA. http://www.nber.org/papers/w8084.pdf

Markusen, J. R. (1997). Trade versus investment liberalisation. NBER Working Paper No.6231. National Bureau of Economic Research, Cambridge, MA.

Markusen, J. R. (1984). Multinationals, multi-plant economies, and the gains from trade. Journal of International Economics, 16, 205-266. http://dx.doi.org/10.1016/S0022-1996(84)80001-X

Michel, A., \& Shaked, I. (1986). Multinational corporations versus domestic corporations financial performance and characteristics. Journal of International Business $\quad$ Studies, $16 . \quad 89-106$. http://dx.doi.org/10.1057/palgrave.jibs.8490435

Obwona, M. B. (2001). Determinants of FDI and their impacts on economic growth in Uganda. African Development Review, 13(1), 46-80. http://dx.doi.org/10.1111/1467-8268.00030

Odozi, V. A. (1995). An overview of foreign investment in Nigeria 1960-1995. Occasional Paper No. 11. Research Department, Central Bank of Nigeria.

Oke, B. O. (2001). The Determinants of Foreign Direct Investments in Nigeria. (Unpublished MSc Finance Dissertation). University of Lagos, Nigeria.

Okwo, E. (1999, July 9). Agency unfolds Nigeria's quest for investment, promotional strategies. The Guardian, pp. 21-22.

Olewuenyi, E. (2000, January 9). Business without borders. Financial Standards Newspaper, pp. 20-21.

Papanastassiou, M., \& Pearce, R. D. (1990). Host Country Characteristics and the Sourcing Behaviour of U.K Manufacturing Industry. University of Reading, Department of Economics. Discussion Papers in International Investment and Business Studies, Series B. Vol II. No. 140.

Prakash, L., \& Assaf, R. (2001). How beneficial is foreign direct investment for developing countries. Finance and Development, 38(2), 7-9. http://www.imf.org/external/pubs/ft/fandd/2001/06/loungani.htm

Root, F. R. (1990). International Trade and Investment (5th ed.) (pp. 425-469). South Western Publishing Co.

Root, F. R., \& Ahmed, A. A. (1979). Empirical determinants of manufacturing direct foreign investment in developing countries. Economic Development and Cultural Change, 27(4), 751-767. http://dx.doi.org/10.1086/451139

Rugman, A. M. (1981). Inside the Multinationals. London: Croom Helm.

Schneider, F., \& Frey, B. S. (1985). Economic and political determinants of foreign direct investment. World Development, 13(2), 161-75. http://dx.doi.org/10.1016/0305-750X(85)90002-6

Sodersten, B., \& Reed, G. (1994). International Economics (3rd ed.). London: Macmillan Press Ltd. 
Swedenborg, B. (1979). The Multinational operations of Swedish Firms: An Analysis of Determinants and Effects. Stockholm: Industriens Utredningsinstitut.

Vernon, R. (1966). International investment and international trade in the product cycle. Quarterly Journal of Economics, 80, 190-207. http://dx.doi.org/10.2307/1880689

World Bank. (2010). World Development Indicators. Washington, D.C.: The World Bank.

World Bank. (2011). Migration and Remittances Factbook 2011. The International Bank for Reconstruction and Development / The World Bank, 2nd Edition.

WTO. (1996). International Trade, Trends and Statistics (pp. 44-81). Geneva: WTO.

Table 1. Resource Flows to Nigeria US\$ Millions

\begin{tabular}{lllllllll}
\hline & 1995 & 2000 & 2004 & 2005 & 2006 & 2007 & 2008 & 2009 \\
\hline FDI & 1079.27 & 1140.14 & 1874.03 & 4982.53 & 8824.80 & 6033.00 & 4876.45 & 5786.68 \\
Remittances & 804.00 & 1391.80 & 2272.70 & 3328.70 & 5435.00 & 9221.00 & 9980.00 & 9584.75 \\
\hline
\end{tabular}

Source: World Bank (2011) "Migration and Remittances Factbook 2011” The International Bank for Reconstruction and Development / The World Bank, 2nd Edition.

Table 2. GMM Estimates

\begin{tabular}{lllll}
\hline Dependent Variable: Log(FDI) & & & & \\
\hline Variables & Coefficient & Std. Error & t-Statistic & P Value \\
\hline Log(INF) & 0.1633 & 0.1569 & 1.0408 & 0.3088 \\
Log(GDP) & -0.1612 & 0.1541 & -1.0524 & 0.3036 \\
Log(INFDEV) & -1.9786 & 1.3567 & -1.4584 & 0.1583 \\
Log(GOVEXP) & 0.9449 & 0.2018 & 4.6820 & $0.0001^{* * *}$ \\
Log(HCAP) & 1.2062 & 1.4679 & 0.8217 & 0.4197 \\
POLSTAB & 0.6514 & 0.1638 & 3.9777 & $0.0006^{* * *}$ \\
Log(IEC) & 0.7433 & 0.3489 & 2.1304 & $0.0440^{* *}$ \\
Log(EXCR) & 0.1902 & 0.2046 & 0.9298 & 0.3621 \\
AR(1) & -0.4782 & 0.2068 & -2.3119 & 0.0301 \\
C & 16.1084 & 15.5143 & 1.0383 & 0.3099 \\
R-squared & 0.9438 & & & \\
Adjusted R-squared & 0.9218 & & & \\
Durbin-Watson stat & 2.2425 & & & \\
J-statistic & $4.68 \mathrm{E}-18$ & & & \\
Observations & 33 & & & \\
Period Covered & $1975-2008$ & & & \\
\hline
\end{tabular}

Source: Authors computation (2011) using EViews 7 statistical package.

Note: ${ }^{* * *}$ Significant at 1 percent level; ${ }^{* *}$ Significant at 5 percent level.

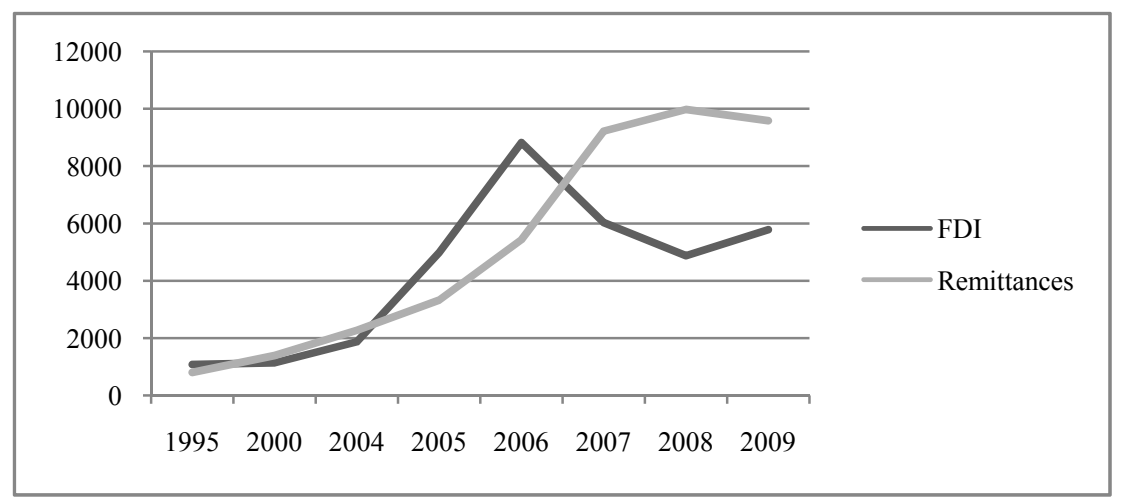

Figure 1. Resource Flows to Nigeria US\$ Millions

Source: Authors computation (2011) using EViews 7 statistical package. 